\title{
Inequality and academic achievement in Chile
}

\author{
Pablo Muñoz H. and Amaia Redondo S.
}

ABSTRACT

This work uses a set of panel data to contribute new evidence on the impacts of socioeconomic determinants on academic achievement in Chile. Socioeconomic determinants are found to have a statistically significant effect, which rises over time, on academic achievement. The evidence shows that two individuals of different socioeconomic levels (SEL) who achieve the same score in Chile's Educational Quality Measurement System (SIMCE) in eighth grade, are separated by a gap of over 70 points on average four years later, when they sit the University Selection Test (PSU). It is concluded that in a context of great income inequality and high returns on tertiary education, academic achievement indexes throw up barriers to access to tertiary education, principally for the population of low socioeconomic level, thereby perpetuating poor income distribution. models, Chile 


\section{I}

\section{Introduction}

A number of studies prepared by international agencies, including the Economic Commission for Latin America and the Caribbean (ECLAC), the World Bank and the Inter-American Development Bank (IDB), have identified persistently high levels of income distribution inequality as a hallmark of Latin America. Around 2005, the Gini coefficient was about 0.53 and Latin America was more unequal than sub-Saharan Africa, East Asia and the high income countries by $18 \%, 36 \%$ and $65 \%$, respectively.

In Declining Latin American Inequality: Market Forces or State Action, Luis López-Calva and Nora Lustig (2010) showed that inequality in the region began to decline in 2000. In Mexico, Argentina, Peru and Brazil two main factors underlie the decrease in inequality: narrowing of the income gap between skilled and unskilled workers, and an increase in government transfers to the most vulnerable sectors. Nevertheless, a projection of constant inequality decline is unlikely, because the low-income population which has managed to gain access to primary and secondary education still faces a range of access barriers when it comes to tertiary education. ${ }^{1}$

Within the region, Chile has posted outstanding rates of economic growth in the past few decades and poverty has declined as a result. However, it has been shown empirically that in high-growth conditions, poverty reduction and variations in income inequality are not necessarily correlated. ${ }^{2}$ In this regard, Chile is a fairly unequal country; its Gini coefficient is the highest within the Organization for Economic Cooperation and Development (OECD), and relative poverty is high as well (approximately 1 in 5 are poor in relative terms). Differences in education level among the workforce have traditionally been cited as a possible explanation for income inequality. ${ }^{3}$ That is, graduates from tertiary education capture higher returns, because demand for skilled labour exceeds supply in the Chilean labour market, but this is not the case for unskilled labour.

1 Luis López-Calva and Nora Lustig (2010) note that these barriers relate basically to the low quality of primary and secondary education in Latin America.

2 See Contreras (1996).

3 See Contreras and Gallegos (2011).
A series of reforms were made to education in Chile in the early 1980s. A voucher system was created whereby publicly funded schools (administered by municipalities) and subsidized private schools receive a direct subsidy for each student enrolled. The main quality assurance mechanism in Chile's education system is free entry to the education market and competition between schools, with little State intervention.

Following this reform, the number of subsidized private schools burgeoned, from $30 \%$ of total enrolments in 1986 to $48 \%$ in 2008, while the percentage of students attending fully private schools (7\%) varied little. Generally speaking, students in fully private schools come from families with a high socioeconomic level, whereas those in municipal schools come mainly from the first two income quintiles. Students attending subsidized schools come from families with differing socioeconomic levels, ${ }^{4}$ mainly quintiles 3 and 4, although the income level of these quintiles is well below that of the middle class in other OECD countries (Chile's average adjusted household income is $38 \%$ the OECD average ${ }^{5}$ ).

Chile has improved education coverage in the past few decades, but not its quality or equity. The reform increased socioeconomic and cultural segregation, ${ }^{6}$ while the voucher system has not driven competition capable of guaranteeing greater efficiency, but has led to a state of equilibrium in which schools skim the market to minimize risk and gain quality at the cost of stratification. ${ }^{7}$ This skimming process, as suggested by Epple and Romano (1998), has restricted the quality of education available to the poor. ${ }^{8}$ In practice, the most expensive private schools have far more resources per student than municipal schools, or than the subsidized schools located in the most vulnerable areas. Several studies show that student socioeconomic background is one of the main determinants of learning outcomes, while the socioeconomic level of fellow students can have an even stronger impact (OECD, 2007). Teaching

\footnotetext{
4 This is because a shared financing system operates in Chile: the State subsidizes school establishments and families make a co-payment as well.

5 According to the OECD Better Life Index (2012).

6 See Valenzuela (2006).

7 See Contreras, Sepúlveda and Bustos (2007).

8 See Hsieh and Urquiola (2006).
} 
students at social risk is difficult and therefore costly, especially if they are concentrated in the same school. Other data show that parents have little information about school quality (Elacqua and Fábrega, 2004), and access to and use of this information depends, as well, on socioeconomic status. Lower-income parents also attribute particular value to the distance between home and school, regardless of the quality of education (Chumacero, Gómez Caorsi and Paredes, 2008; Gallego and Hernando, 2009).

All this reduces the incentive for schools to improve quality to attract students. And Chile's greatest challenges lie precisely in quality, since although the country's scores in the Programme for International Student Assessment (PISA) improved considerably between 2000 and 2009, the scores for 15-year-olds in science, reading and mathematics remain well below the OECD average, even after adjusting for income level. In Chile PISA scores fall, depending on the type of school, in direct relation to students' socioeconomic background.

Since the 1981 reform, the system of tertiary education in Chile has been divided into two main groups: the private universities and those grouped under the Council of Rectors of Chilean Universities (CRUCH). CRUCH universities account for the largest portion of matriculations in tertiary education and they select students by means of a common admissions system. ${ }^{9}$ Since 2003, the admissions system under CRUCH consists of using the results of the various university selection examinations (University Selection Test, PSU, in language, maths, science and history) as discrimination factors, in combination with applicants' average secondary education grade (nota de enseñanza media, NEM). ${ }^{10}$ The 2013 admissions process included an additional measurement instrument, which ranks students by academic achievement in secondary school and rewards relative position within each educational establishment. ${ }^{11}$ The rationale for this measure was the fact, as shown by various authors, that indices such as relative ability not only lessen socioeconomic exclusion, but are also good predictors of performance in tertiary education, even after controlling for PSU scores. ${ }^{12}$

\footnotetext{
9 Information from the Council of Rectors shows that eight private universities, as well as the 25 traditional CRUCH universities that participated previously, entered the common admissions process in 2012.

10 See Contreras, Gallegos and Meneses (2009).

11 See DEMre (2012) and CRUCH (2012).

12 See Contreras, Gallegos and Meneses (2009).
}

The factors mentioned are weighted differently depending on each particular course and university, with a view to predicting academic success over the university career. Those with higher scores therefore have more options to choose between universities and courses, and thus have better access to the high returns which some of these offer.

It has been shown that results in Chile's Educational Quality Measurement System (SIMCE) are heavily conditioned by socioeconomic factors ${ }^{13}$ and that social mobility is limited (Núñez and Risco, 2004). Several authors ${ }^{14}$ consider education a key determinant and attribute inequality in learning quality to socioeconomic variables. One of these variables is the students' socioeconomic background, which is determined by family income and by the type of school they attended. ${ }^{15}$

This research offers new evidence with respect to the impact of certain socioeconomic determinants on academic achievement. First, it demonstrates that socioeconomic variables are statistically significant in explaining levels of achievement in both PSU and SIMCE. Second, using a set of panel data and tracking individuals at two points in time (at the time of the SIMCE and PSU), it re-examines the role of socioeconomic determinants, now controlling for two categories: high and low socioeconomic level. The evidence shows that two individuals of different socioeconomic level — as measured by family income and parents' level of education-who achieve the same SIMCE scores in eighth grade, have a gap of over 70 points on average four years later when they sit the PSU. In other words, the academic achievement gaps do not narrow, but grow wider. This is all the worse because the outcomes of PSU determine access to tertiary education and the high private returns it brings. ${ }^{16}$ This represents evidence that the Chilean education system has not been efficient in offsetting differences of origin among students.

Following this introduction, section II se examines the panel data containing the results of the SIMCE and PSU tests, in the light of the corresponding variables. Section III uses production function and value added approaches to analyse the results of those tests as a function of a vector of socioeconomic variables. Section IV sets forth and discusses the findings of the research. Section V concludes.

\footnotetext{
13 See Mizala and Romaguera (2000).

14 See Brunner and Elacqua (2003); Cornejo (2005).

15 See Contreras and Macías (2002).

16 The evidence presented here also shows that the gap in SIMCE achievement is widening.
} 


\section{II}

\section{Data}

This article uses a set of panel data, which includes the SIMCE and PSU scores of the full sample of students (a total of 99,736) in secondary education in 2001 and 2004. Specifically, the scores used were the SIMCE obtained in 2000 (eighth grade) and the PSU obtained in 2004 (twelfth grade school-leavers) by each of the students. That is, the scores available were those obtained by the same individual at two different points in time.

The NEM variable corresponds to the grades obtained in secondary education, which are used in this article to identify each student's relative position within his or her school.

The dataset also includes a series of variables corresponding to student socioeconomic characteristics at the time of taking the PSU, and other factors relating to the schools they were attending when they took the SIMCE. The socioeconomic variables considered included gender, income of the family group and the parents' level of education. With respect to the school, the variables include administrative type, geographical area and modality of education.

Students who did not sit the PSU in 2004 were excluded from the SIMCE, as were those who did not graduate from secondary school that year.

The description of the variables is shown in table 1 .

Table 2 shows the descriptive statistics of the variables used.

TABLE 1

\section{Description of variables}

\begin{tabular}{|c|c|}
\hline Variable & Description \\
\hline \multicolumn{2}{|l|}{ SIMCE score } \\
\hline Language & Score obtained in SIMCE language test \\
\hline Mathematics & Score obtained in SIMCE mathematics test \\
\hline Average & Average of sIMCE scores in language and mathematics \\
\hline \multicolumn{2}{|l|}{ PSU score } \\
\hline Language & Score obtained in PSU language test \\
\hline Mathematics & Score obtained in PSU mathematics test \\
\hline Average & Average of PSU scores in language and mathematics \\
\hline \multicolumn{2}{|l|}{ Student variables } \\
\hline Sex & $1=$ Female, $0=$ Male \\
\hline NEM & Relative position in school by secondary education grades \\
\hline \multicolumn{2}{|l|}{ Socioeconomic variables } \\
\hline Income of family group & $\begin{array}{l}1=[\mathrm{CH} \$ 0-\mathrm{CH} \$ 278,000] ; 2=[\mathrm{CH} \$ 278,000-\mathrm{CH} \$ 834,000] ; \\
3=[\mathrm{CH} \$ 834,000-\mathrm{CH} \$ 1,400,000] ; 4=[\mathrm{CH} \$ 1,400,000 \text { or more }]\end{array}$ \\
\hline $\begin{array}{l}\text { Level of education } \\
\text { mother/father }\end{array}$ & $\begin{array}{l}1=\text { no schooling, } 2=\text { incomplete primary, } 3=\text { complete primary, } \\
4=\text { incomplete secondary, } 5=\text { complete secondary, } 6=\text { incomplete тт, } 7=\text { complete } \mathrm{TT}, 8=\text { incomplete university, } \\
9=\text { complete university, } 10=\text { other studies }\end{array}$ \\
\hline \multicolumn{2}{|l|}{ School variables } \\
\hline \multicolumn{2}{|l|}{ Administrative type: } \\
\hline -Municipal & $1=$ municipal, $0=$ other \\
\hline -Subsidized private & $1=$ subsidized private, $0=$ other \\
\hline -Fully private & $1=$ paid private, $0=$ other \\
\hline Geographical area & $1=$ rural, $0=$ urban \\
\hline Modality & $0=$ technical $/$ vocational, $1=$ science $/$ humanities \\
\hline
\end{tabular}

Source: prepared by the authors, on the basis of data from the Educational Quality Measurement System (SIMCE) 2000 and the University Selection Test (PSU) 2004.

Тт: technical training.

NEM: average grades in secondary school. 
TABLE 2

\section{Descriptive statistics of the variables}

\begin{tabular}{|c|c|c|c|c|}
\hline Variables & Average & Deviation & Minimum & Maximum \\
\hline \multicolumn{5}{|l|}{ SIMCE score } \\
\hline Language & 276 & 47 & 109 & 395 \\
\hline Mathematics & 277 & 47 & 118 & 382 \\
\hline Average & 276 & 42 & 128 & 388 \\
\hline \multicolumn{5}{|l|}{ PSU score } \\
\hline Language PSU & 499 & 111 & 167 & 850 \\
\hline Mathematics PSU & 501 & 112 & 150 & 850 \\
\hline Average & 500 & 104 & 198 & 840 \\
\hline \multicolumn{5}{|l|}{ Student variables } \\
\hline Female & $54 \%$ & 0.50 & 0 & 1 \\
\hline Scores & 0.52 & 0.29 & 0.001 & 1 \\
\hline \multicolumn{5}{|l|}{ Sociocultural variables } \\
\hline \multicolumn{5}{|l|}{ Family income: } \\
\hline - Level $1=[\mathrm{CH} \$ 0-\mathrm{CH} \$ 278,000]$ & $55 \%$ & 0.50 & 0 & 1 \\
\hline- Level $2=[\mathrm{CH} \$ 278,000-\mathrm{CH} \$ 834,000]$ & $31 \%$ & 0.46 & 0 & 1 \\
\hline- Level $3=[\mathrm{CH} \$ 834,000-\mathrm{CH} \$ 1,400,000]$ & $7 \%$ & 0.26 & 0 & 1 \\
\hline - Level $4=[\mathrm{CH} \$ 1,400,000$ ormore $]$ & $7 \%$ & 0.26 & 0 & 1 \\
\hline Education mother & 5.4 & 2.2 & 1 & 10 \\
\hline Education father & 5.6 & 2.4 & 1 & 10 \\
\hline \multicolumn{5}{|l|}{ School variables } \\
\hline \multicolumn{5}{|l|}{ Administrative type: } \\
\hline - Municipal & $40 \%$ & 0.49 & 0 & 1 \\
\hline - Subsidized private & $43 \%$ & 0.49 & 0 & 1 \\
\hline - Fully private & $17 \%$ & 0.37 & 0 & 1 \\
\hline Rural & $6 \%$ & 0.23 & 0 & 1 \\
\hline Science/humanities modality & $77 \%$ & 0.42 & 0 & 1 \\
\hline
\end{tabular}

Source: prepared by the authors, on the basis of data from the Educational Quality Measurement System (SIMCE) 2000 and the University Selection Test (PSU) 2004.

The SIMCE scores are observed to range from just over 100 to just under 400 points, with an average of around 280, while the PSU scores range from 150 to 850 , with an average of 500. The gross SIMCE score is adjusted or standardized to obtain a median of 250 points and a deviation of 50 points. This is because the sample for this study includes the SIMCE scores only of those students who also sat the PSU in 2004. In other words, the data exclude the SIMCE scores of those who did not sit the PSU in 2004.

Females represent $54 \%$ of the sample. Students who take the PSU have an average relative ranking in their schools of 0.52 , with a deviation of $20 \%$.

Most of the students belong to the first income level (55\%), $31 \%$ to the second and only $7 \%$ to each of the higher levels. With respect to school administrative type, $40 \%$ of students attend municipal schools, $43 \%$ subsidized private schools and only $17 \%$ fully private schools.

The average level of parental education is around 5, corresponding to complete secondary education, and is slightly higher among fathers than mothers.

Lastly, $6 \%$ of students study in rural areas, and $77 \%$ attend science/humanities schools, with the remaining $22 \%$ attending vocational training schools.

It is important to bear in mind the average SIMCE and PSU scores for the different income levels, and the average schooling of parents and composition of the sample of the different types of schools by administrative type. Descriptive statistics are shown in annex table A1.

It stands out clearly that the higher the income level, the higher students' scores in language and mathematics in both SIMCE and PSU. It is also apparent that students from higher income levels have more highly educated parents, on average. Furthermore, students in municipal schools come essentially from the first income level, while subsidized schools have students mainly from the first and second levels. In private schools, the situation is just the reverse, with students mainly from the highest and second highest income levels. 


\section{III}

\section{Methodology}

This study uses the results obtained by the same individual at two points in time in the SIMCE and PSU tests, which are instruments designed to assess student knowledge and are highly correlated $\left(75 \%{ }^{17}\right)$. This work uses the production function approach proposed by McEwan and Carnoy (1999), with the test scores understood as the output of a set of student-linked variables. Accordingly, the results of the SIMCE and PSU tests are examined as a function of a vector of socioeconomic variables, which includes type of establishment, student characteristics and other factors. The results of this regression are presented in the annexes (general model, annex table A2) and confirm the potential of the socioeconomic variables in explaining the scores obtained.

Having confirmed the statistical significance of the socioeconomic determinants of student performance, the study then sets out to determine the extent to which conditions endogenous to the individual influence his or her levels of academic achievement. As noted above, the PSU and SIMCE tests are highly correlated, so that by controlling for one of them it may be supposed that the repercussion of the other variables corresponds to the effect on performance over time, i.e. the second-order effect of socioeconomic variables on achievement. It is proposed to estimate a specification using a fixed effects model, taking the results of the same individuals at two points in time. The model proposed therefore at least partly eliminates the effect of non-observable variables on the results.

In order to examine the contribution of socioeconomic variables over time, two dichotomous variables were chosen: $S E L_{\text {low }}$, which takes a value of 1 when the individual has a family income of less than 278,000 Chilean pesos (CH\$), and $S E L_{h i g h}$, whose value is 1 when the individual has a family income of over CH $\$ 1,400,000$. An additional student classification by parental education level was estimated separately. This distinction was made from a cultural perspective, following Bourdieu and Passeron (1964), who argue that the great majority of students who do well in school come from families endowed with a high level of schooling, and therefore

17 See details in annex table A3. possess a cultural capital which their children inherit through socialization in the home from the earliest ages. These children are equipped with experiences, knowledge, language forms and attitudes which give them a considerable advantage with respect to school and the learning that occurs there. On this basis, two new dichotomous variables were created: low parental educational level (Edlev low $)$, whose value is 1 for students whose parents did not complete primary schooling, and high parental educational level $\left(E d l e v_{\text {high }}\right)$, for students whose parents have university studies. The main model is as follows:

$$
\begin{aligned}
& P S U_{t}=\alpha+\beta_{1} \text { Subsidized priv. }+ \\
& \beta_{2} \text { Fully priv. }+\beta_{2} \text { Modality }+ \\
& \beta_{4} \text { Gender }+\beta_{5} \text { Parent education }+\varepsilon_{t}
\end{aligned}
$$

In equation (1) the dependent variable is the PSU score (average for language and mathematics), and the explanatory variables are: (i) school administrative type (subsidized private, fully private, and municipal as an omitted variable); (ii) the modality of studies (science/ humanities establishments versus vocational training establishments); (iii) gender: which identifies the impact of being female; (iv) rural location; (v) average educational level of parents (from $1=$ no schooling to $10=$ postgraduate studies); (vi) family income grouped in four levels; and, lastly, (vii) the student's relative position in his or her establishment as defined by average secondary school grades (NEM).

The specification also includes the score obtained by the same student four years earlier in the SIMCE test as a regression factor. The aim is thus to ascertain the additional effect of variables already captured implicitly in the SIMCE score, given that:

$$
\begin{aligned}
& \text { SIMCE }_{t-4}=\alpha^{-}+\beta_{1}^{-} \text {Subsidized priv. }+ \\
& \beta_{2}^{-} \text {Fully priv. }+\beta_{2}^{-} \text {Modality }+\beta_{2}^{-} \text {Gender }+ \\
& \beta_{5}^{-} \text {Parent education }+\varepsilon_{\mathrm{t}}
\end{aligned}
$$


Equation (1) also reflects a value added approach in the estimation of an achievement production function. In this regard, the literature indicates that evidence based on this type of specification is generally preferred to that obtained from contemporary information (Hanushek, 1996; Krueger, 2000; Todd and Wolpin, 2003) because it clears, at least partially, the effect of non-observable variables on the results.

According to Todd and Wolpin (2003), a value added specification requires suppositions about the behaviour of non-observable variables and is therefore subject to endogeneity problems. One of the main criticisms levelled at this type of model is that if the behaviour of the agents is optimal, then families should be expected to take decisions based on the students' baseline achievement (SIMCE $E_{\mathrm{t}-4}$ in this case). In Chile, however, families are not informed of SIMCE results, so cannot take decisions on this basis. This adds value to the specification contributed in this study, because it lessens the endogeneity bias.

In conclusion, this model is intended to evaluate the effect and statistical significance of socioeconomic determinants on academic achievement. The specification also makes it possible to assess whether the impact of the factors increases over time.

The following models are defined in addition to equation (1):

$$
\begin{aligned}
& P S U_{t}=\alpha+\beta_{1} S_{M C E E_{t-4}}+ \\
& \beta_{2} S E L_{\text {high }}+\beta_{3} S E L_{\text {low }}+\varepsilon_{t} \\
& \\
& P S U=\alpha+\beta_{1} S I M C E_{t-4}+\beta_{2} S E L_{\text {high }}+ \\
& \beta_{3} S E L_{\text {low }}+\beta_{4} S E L_{\text {high }} S I M C E_{t-4}+ \\
& \beta_{5} S E L_{\text {low }} S I M C E_{t-4}+\varepsilon_{t}
\end{aligned}
$$

Equation (2) tests for the PSU performance differential driven exclusively by socioeconomic level (SEL), for which it is necessary to control for SIMCE performance. Equation (3) includes interaction variables between SIMCE achievement and socioeconomic level, with a view to lessening the supposition that the difference between the two groups' achievement, if it exists, is constant. These specifications have been included in order to show clearly the effect of high and low socioeconomic level on PSU results, controlling for SIMCE. ${ }^{18}$

18 Equations (2) and (3) do not consider the regression vectors from (1), because most of these controls are highly correlated with the average socioeconomic level. The sign and significance of the results is maintained if all the controls are included; this estimate is reported in annex table A4.

\section{IV}

\section{Results and discussion}

All the variables were significant and the effects were aligned with the classic model developed by Mizala and Romaguera (2000), which confirms that in Chile socioeconomic determinants impact academic achievement. In addition, however, new evidence is provided that the impact of these factors grows over time. This may be because individuals with better economic circumstances can keep making a larger investment over time and, therefore, may expect a higher return (in this case, a higher score). Nevertheless, the key point here is that greater exposure to an unfavourable socioeconomic context increases the limitations students face in securing a good PSU score and thus gaining access to tertiary education.

Table 3 shows the estimations of the model specified in equation (1). 
TABLE 3

Determinants of the University Selection Test (PSU) score

\begin{tabular}{|c|c|c|c|}
\hline Variables & PSU MATH & PSU LANG & PSU \\
\hline Subsidized & $7.542 * * *$ & $10.93 * * *$ & $8.505^{* * *}$ \\
\hline Private & $33.35 * * *$ & $32.91 * * *$ & $30.46 * * *$ \\
\hline Modality & $42.36 * * *$ & $35.87 * * *$ & $37.62 * * *$ \\
\hline Female $=1$ & $-33.54 * * *$ & $-21.35^{* * *}$ & $-27.45^{* * *}$ \\
\hline Schooling parents & $5.068 * * *$ & $6.488 * * *$ & $5.117 * * *$ \\
\hline Rural & $-19.66^{* * *}$ & $-21.03 * * *$ & $-18.98 * * *$ \\
\hline Family income & $10.46^{* * *}$ & $8.943 * * *$ & $9.095^{* * *}$ \\
\hline NEM (relative) & $95.87 * * *$ & $94.38 * * *$ & $84.80 * * *$ \\
\hline SIMCE Math & $1.174 * * *$ & & \\
\hline SIMCE Lang & & $1.157 * * *$ & \\
\hline SIMCE & & & $1.345^{* * *}$ \\
\hline Constant & $58.51 * * *$ & $54.76 * * *$ & $18.81 * * *$ \\
\hline No. observations & 87417 & 87417 & 87417 \\
\hline R-squared & 0.647 & 0.601 & 0.713 \\
\hline
\end{tabular}

Source: prepared by the authors, on the basis of data from the Educational Quality Measurement System (SIMCE) 2000 and the University Selection Test (PSU) 2004.

Note: $* * * \mathrm{p}<0.01$.

PSU MAT: PSU mathematics.

PSU LENG: PSU language.

SIMCE Math: SIMCE mathematics.

SIMCE Lang: SIMCE language.

NEM: average grades in secondary school.

On the basis of these results, it was considered worthwhile to look in more detail at the impacts of the socioeconomic variables, for which the model specified in equation (2) was estimated. The results observed were as follows:

TABLE 4

University Selection Test (PSU), by income

\begin{tabular}{lc}
\hline Variables & PSU \\
\hline SIMCE & $1.710^{* * *}$ \\
SEL $_{\text {high }}$ & $43.08^{* * *}$ \\
SEL low & $-31.30^{* * *}$ \\
Constant & $41.50^{* * *}$ \\
No. observations & 99706 \\
R-squared & 0.617 \\
\hline
\end{tabular}

Source: prepared by the authors, on the basis of data from the Educational Quality Measurement System (SIMCE) 2000 and the University Selection Test (PSU) 2004.

Note: $* * * \mathrm{p}<0.01$.

SEL: socioeconomic level.

It may be directly observed that, on average, for the same SIMCE performance, individuals with a high socioeconomic level $\left(\mathrm{SEL}_{\text {high }}\right)$ performed better in the PSU than those with a low socioeconomic level ( $\left.\mathrm{SEL}_{\text {low }}\right)$, with the difference averaging 70 points.
One of this model's limitations is the assumption that the difference in the two groups' performance is constant. Accordingly, an interaction variable was included for SIMCE achievement level and the socioeconomic determinant, in order to capture the additional returns of each SIMCE point at the different socioeconomic levels. This is the return on the marginal variation in SIMCE performance. Estimation of the model specified in equation (3), then, gives the following results:

TABLE 5 University Selection Test (PSU), by income
and interaction with SIMCE

\begin{tabular}{lc}
\hline Variables & PSU \\
\hline SIMCE & $1.784 * * *$ \\
SEL $_{\text {high }}$ & $65.37 * * *$ \\
SEL $_{\text {low }}$ & 3.637 \\
SEL $_{\text {high }}$ SIMCE & $-0.0782 * * *$ \\
SEL $_{\text {low }}$ SIMCE & $-0.126 * * *$ \\
Constant & 20.63 \\
No. observations & 99706 \\
R-squared & 0.617 \\
\hline
\end{tabular}

Source: prepared by the authors, on the basis of data from the Educational Quality Measurement System (SIMCE) 2000 and the University Selection Test (PSU) 2004.

Note: $* * * \mathrm{p}<0.01$.

SEL: socioeconomic level. 
Given the parameters estimated in the previous regressions, and in order to analyse the results better, the PSU scores that would be expected by socioeconomic level are shown here:

$$
\begin{aligned}
& P S U\left(S E L_{h i g h}=1\right)=85.9+1.71 * \operatorname{SIMCE} \\
& \operatorname{PSU}\left(S E L_{\text {low }}=1\right)=24.3+1.66 * \operatorname{SIMCE}
\end{aligned}
$$

The statistical significance of both gradients was tested, ${ }^{19}$ and the possibility of no significant difference between them was ruled out with a confidence level of $99 \%$.

19 The significance test is shown in the annex.

FIGURE 1

PSU compared with SIMCE, by socioeconomic level (SEL)

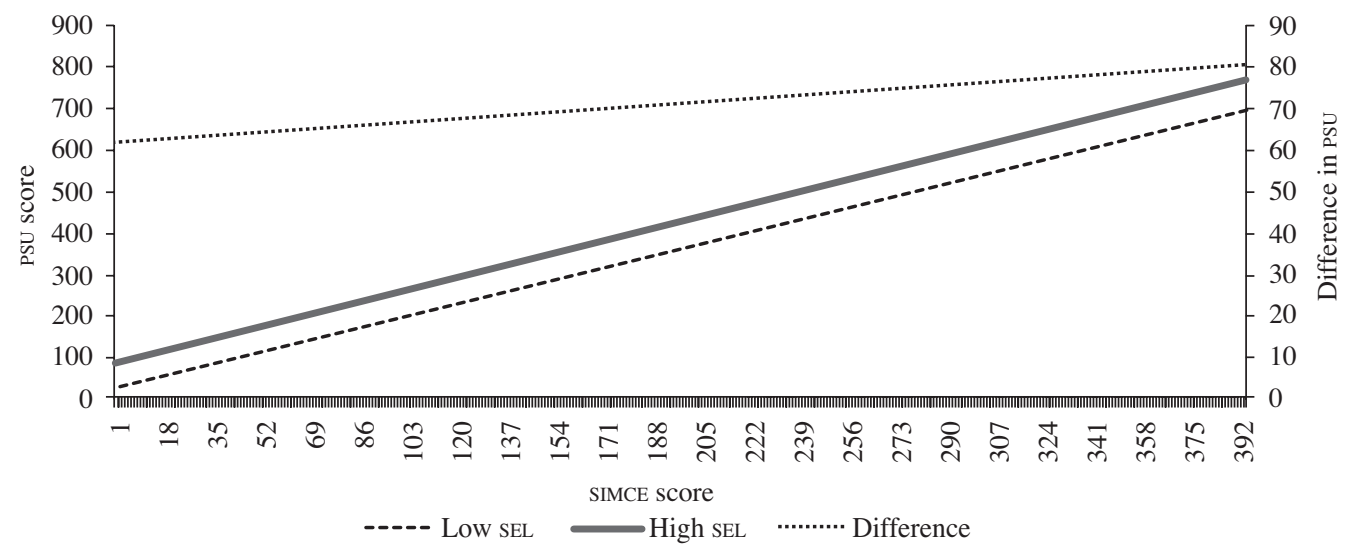

Source: prepared by the authors, using the results shown in table 5, on the basis of data from the Educational Quality Measurement System (SIMCE) 2000 and the University Selection Test (PSU) 2004.

On average, for the same SIMCE score, individuals with low socioeconomic level perform worse in the PSU for all SIMCE score levels. What is more, the higher the SIMCE score, the greater the effect of socioeconomic level on the PSU score.

The gap by socioeconomic level is close to 70 points on the PSU score, rising from 60 points for the worst performing students at SIMCE to 80 points for the best performing.

So, if two individuals with the same academic performance at one point in time (SIMCE) are picked at random, one with a high and the other with a low socioeconomic level, the first is then observed to score 70 points more than the second in the PSU. What is more, the gap in score is higher in students with better SIMCE scores: in other words, the higher the academic achievement at the earlier point in time, the greater the penalty or premium by level of income.

A PSU performance gap by socioeconomic level has therefore been shown to exist for students with the same sIMCE score. Individuals with favourable socioeconomic determinants achieve better scores than those in vulnerable situations, and the higher the SIMCE score, the larger the gap.

The model specified in equation (3) was also estimated using a cultural approach to socioeconomic level, i.e. linking it with the education level of parents. The results were as follows:

TABLE 6

PSU by education level of parents and SIMCE interaction variable

\begin{tabular}{lc}
\hline Variables & PSU \\
\hline SIMCE & $1.742^{* * *}$ \\
Low edlev & $16.57^{* *}$ \\
High edlev & $37.67^{* * *}$ \\
Low edlev SIMCE & $-0.175^{* * *}$ \\
Low edlev sIMCE & $0.0293^{*}$ \\
Constant & $13.88^{* * *}$ \\
No. observations & 87638 \\
R-squared & 0.605 \\
\hline
\end{tabular}

Source: prepared by the authors, on the basis of data from the Educational Quality Measurement System (SIMCE) 2000 and the University Selection Test (PSU) 2004.

Note: $* * * \mathrm{p}<0.01,{ }^{* *} \mathrm{p}<0.05, * \mathrm{p}<0.1$

edlev: education level. 


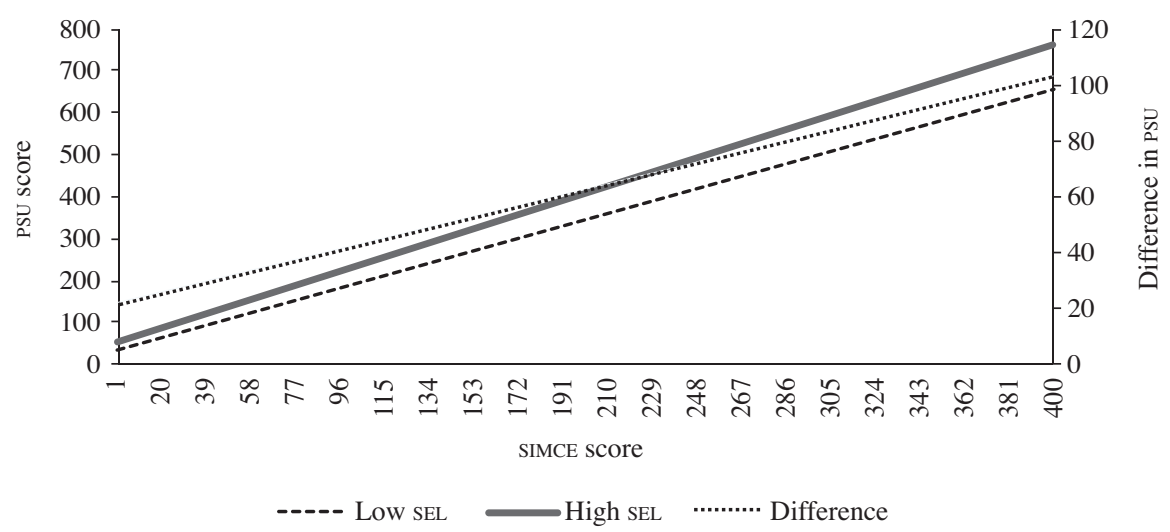

Source: prepared by the authors using the results shown in table 5, on the basis of data from the Educational Quality Measurement System (SIMCE) 2000 and the University Selection Test (PSU) 2004.

SEL: socioeconomic level.

As occurred with income level, for students with the same SIMCE score, there is a large gap in PSU scores between those with poorly educated parents and those whose parents are highly educated.

This gap, too, increases with respect to SIMCE performance: the higher the SIMCE score the larger the difference between the two groups, from 20 points for students with the lowest SIMCE scores to 100 points for those who scored high on SIMCE. On average, individuals with poorly and highly educated parents differ by 60 points in the PSU score.

In sum, the results show that socioeconomic factors impact significantly on scores obtained in both the SIMCE and PSU tests. What is more, the effect of these factors rises significantly over time: for the same individual, differences arise between the achievement level of PSU and that of SIMCE. After controlling for socioeconomic level, the evidence shows PSU gaps averaging 70 points by income level and 60 points by parental education level, for the same level of achievement in SIMCE.

The estimated effect of socioeconomic level on the results is also subject to selection bias, because the data used include only those students who sat the PSU in 2004. Given that students who reach the PSU are generally of higher socioeconomic level, the effects described here could be underestimated.

The significance of the results reported in this work is robust for a two-stage least square specification, with a full-information maximum likelihood estimation. ${ }^{20}$ The robustness of the estimates performed in this study was verified using a new cohort of students taking the SIMCE (2006) and the PSU (2008), and the results obtained were consistent (in terms of the direction of the effect and its significance) with those reported here. ${ }^{21}$

For the purposes of estimation, parents' expectations regarding their children's future studies at the time of the SIMCE were taken as an identification variable. Intuitively, parents' expectations would influence the decision to take the PSU or not, but they do not affect the students' scores on the test, since parents who do not expect their child to enter university education will not provide the means or incentives for the child to register for the PSU, regardless of the students' abilities. Moreover, parents' expectations could reveal planning decisions such as having the student enter the labour market after completing obligatory schooling in order to help the family financially. Although the choice of identification variable could be debated, it may be considered the best option within the possibilities.

The estimate is reported in annex table $\mathrm{A} 6$ and confirms that — correcting for this selection bias— the results hold,

\footnotetext{
20 Puhani (2000) finds that this estimation is preferable to the traditional two-stage Heckman method.

21 The results of equation (3) with the new database are shown in annex table A5.
} 
i.e. there is a significant gap in PSU achievement level by socioeconomic level, controlling for SIMCE score.

The findings presented here indicate that there is a potential talent loss, since a difference of 60 points in the PSU generates limitations on access to tertiary education. In addition, in Chile the PSU score determines not only possibilities of access to the various courses at

\section{$\mathrm{V}$}

\section{Conclusions}

Using panel data it was shown that socioeconomic factors have a positive influence, which grows over time, on student performance. The results also show a significant and growing gap in PSU scores by socioeconomic level (monetary and cultural). Two eighth grade students with the same sIMCE score, but from different socioeconomic levels, show gaps of around 70 points on average in the PSU score. Furthermore, the higher the initial SIMCE score, the wider this gap.

Assuming that non-observable variables (ability, motivation, and so forth) are constant, it may be affirmed that PSU achievement level and, therefore, the possibility of entering tertiary education, are conditioned by factors exogenous to the student, which prevent talent from being expressed in the academic and production arenas.

This work highlights the need to evaluate the potentially regressive nature of the instruments designed each university, but also access to sources of financing, especially State subsidies.

It is evident that human capital formation occurs more intensively among those with greater resources, since there is some complementarity between monetary (and cultural) capital ad human capital, which sharpens inequality in income distribution over time.

to control access to tertiary education. This is important for Chile — and for Latin America generally — because of two structural characteristics: the high returns on tertiary education and the region's high levels of income distribution inequality.

In Chile today, there is an excess demand for workers with higher levels of human capital. This opens up space for developing pro-equality policies, which should guarantee an even threshold for access to tertiary education, assigning human capital to those who are intellectually more productive, not those who randomly face fewer economic or cultural barriers.

It is hoped that the evidence presented will inspire further research into selection mechanisms and lead to policy innovation to promote social mobility, one of the routes towards more growth with equality.

ANNEXES

Descriptive statistics

TABLE A1

Characteristics by socioeconomic level (SEL)

\begin{tabular}{|c|c|c|c|c|c|c|}
\hline Family income & & Level 1 & Level 2 & Level 3 & Level 4 & Total \\
\hline \multirow[t]{2}{*}{ SIMCE } & Mathematics & 266.8 & 281.6 & 297.7 & 310.0 & 276.8 \\
\hline & Language & 267.3 & 280.4 & 293.7 & 303.2 & 275.9 \\
\hline \multirow[t]{2}{*}{ PSU } & Mathematics & 466.9 & 518.0 & 572.3 & 615.2 & 501.1 \\
\hline & Language & 466.6 & 515.5 & 564.4 & 602.4 & 498.7 \\
\hline \multirow[t]{2}{*}{ Education } & Father & 4.45 & 6.33 & 7.91 & 8.49 & 5.62 \\
\hline & Mother & 4.37 & 6.09 & 7.32 & 7.94 & 5.38 \\
\hline \multirow[t]{4}{*}{ Administrative type } & Municipal & 29803 & 9289 & 931 & 255 & 40278 \\
\hline & Subsidized & 23335 & 16077 & 2308 & 720 & 42440 \\
\hline & Private & 1352 & 5243 & 4171 & 6252 & 17018 \\
\hline & Total & 54490 & 30609 & 7410 & 7227 & 99736 \\
\hline
\end{tabular}

Source: prepared by the authors, on the basis of data from the Educational Quality Measurement System (SIMCE) 2000 and the University Selection Test (PSU) 2004. 


\section{- General model}

The results of the score production function general model are presented for both SIMCE and PSU, on the basis of the socioeconomic variables described and using data from SIMCE 2000 and PSU 2004.

The model is as follows:

Score $=\alpha+\beta_{1}$ Subsidized priv. $+\beta_{2}$ Fully priv. $+\beta_{2}$ Modality $+\beta_{4}$ Gender $+\beta_{5}$ Parent education $+\beta_{6} 1$

The parameters of the model were estimated both for the language and mathematics tests, and for the average of the two, for SIMCE and PSU separately. The results were as follows:

TABLE A2

\section{Determinants of performance in SIMCE and PSU tests}

\begin{tabular}{|c|c|c|c|c|c|c|}
\hline Variables & PSU Math & PSU Lang & PSU & SIMCE Math & SIMCE Lang & SIMCE \\
\hline Subsidized & $12.03 * * *$ & $15.90 * * *$ & $13.97 * * *$ & $3.828 * * *$ & $4.292 * * *$ & $4.060 * * *$ \\
\hline Private & $52.43 * * *$ & $48.59 * * *$ & $50.51 * * *$ & $16.26 * * *$ & $13.56^{* * *}$ & $14.91 * * *$ \\
\hline Modality & $51.37 * * *$ & $46.10 * * *$ & $48.74 * * *$ & $7.670 * * *$ & $8.851 * * *$ & $8.261 * * *$ \\
\hline Female $=1$ & $-42.49 * * *$ & $-13.28 * * *$ & $-27.89 * * *$ & $-7.637 * * *$ & $6.962 * * *$ & -0.337 \\
\hline Education parents & $9.161 * * *$ & $10.93 * * *$ & $10.05 * * *$ & $3.482 * * *$ & $3.845 * * *$ & $3.664 * * *$ \\
\hline Rural & $-28.52 * * *$ & $-29.80 * * *$ & $-29.16 * * *$ & $-7.573 * * *$ & $-7.597 * * *$ & $-7.585 * * *$ \\
\hline Family income & $15.39 * * *$ & $11.93 * * *$ & $13.66 * * *$ & $4.216^{* * *}$ & $2.580 * * *$ & $3.398 * * *$ \\
\hline NEM (relative) & $165.9^{* * * *}$ & $158.5^{* * * *}$ & $162.2 * * *$ & $59.62 * * *$ & $55.40 * * *$ & $57.51 * * *$ \\
\hline Constant & $309.5^{* * *}$ & $294.5^{* * *} *$ & $302.0 * * *$ & $213.7 * * *$ & $207.2^{* * * *}$ & $210.5^{* * *} *$ \\
\hline No. observations & 87441 & 87441 & 87441 & 87417 & 87417 & 87417 \\
\hline R-squared & 0.465 & 0.412 & 0.493 & 0.255 & 0.224 & 0.282 \\
\hline
\end{tabular}

Source: prepared by the authors, on the basis of data from the Educational Quality Measurement System (SIMCE) 2000 and the University Selection Test (PSU) 2004.

Note: $* * * \mathrm{p}<0.01$.

SIMCE Lang: SIMCE language.

SIMCE Math: SIMCE mathematics.

NEM: average secondary school grade.

Almost all the variables were significant at the $99 \%$ confidence level and the models also proved to be well adjusted, given that a series of hard-to-measure variables (such as ability) were omitted.

The results coincide with the theory regarding the influence of sociocultural factors on school achievement. In general, parents' education, family income and average secondary education grade were found to have a positive influence on test scores. The school type — private, subsidized private, and science/humanities modality of education — influenced positively the level of achievement on all the tests. Geographically speaking, rural location had a negative impact on test performance, which could reflect the smaller number of schools in rural areas, or difficulties in travelling to place of study. Lastly, the evidence shows that female gender impacts negatively on achievement levels, except in the SIMCE language test.

\section{- SIMCE-PSU correlation:}

TABLE A3

Correlation between PSU and SIMCE test scores

\begin{tabular}{lcc}
\hline Correlation & PSU & SIMCE \\
\hline PSU & 1 & \\
SIMCE & 0.7592 & 1 \\
\hline
\end{tabular}

Source: prepared by the authors, on the basis of data from the Educational Quality Measurement System (SIMCE) 2000 and the University Selection Test (PSU) 2004. 
- Significance test and impact of SIMCE by socioeconomic level.

The null hypothesis, $H_{\mathrm{o}}$, is given by:

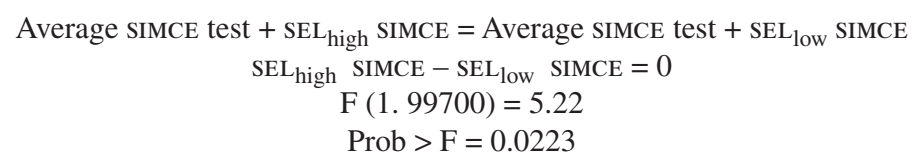

The null hypothesis of non-significance is rejected with a confidence level of $97 \%$.

— Figure A1 shows SIMCE and PSU for the entire population, by socioeconomic level measured by family income: FIGURE A1

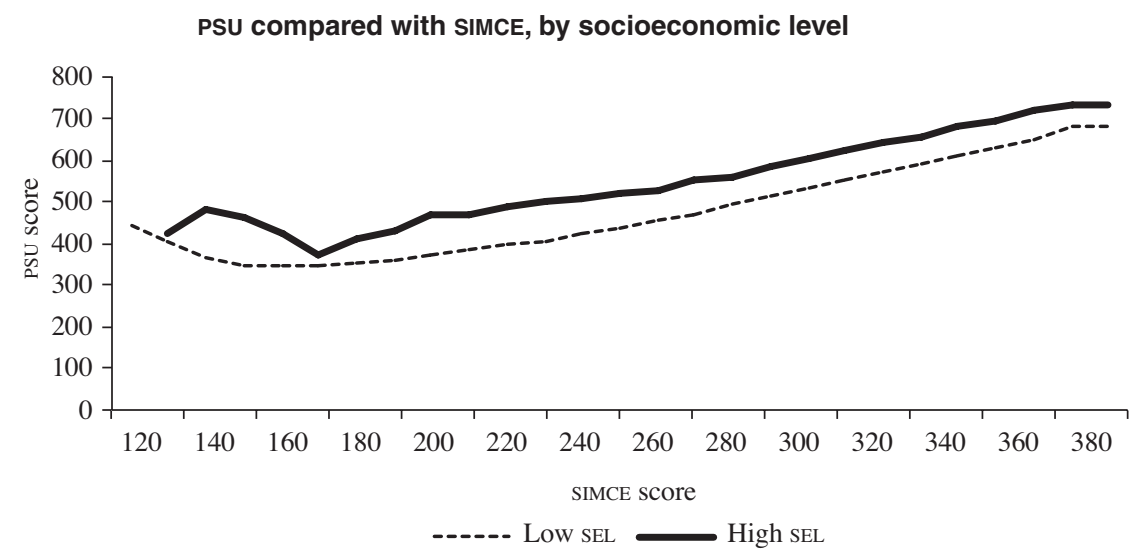

Source: prepared by the authors, on the basis of data from the Educational Quality Measurement System (SIMCE) 2000 and the University Selection Test (PSU) 2004.

SEL: Socioeconomic level.

— Figure A2 shows SIMCE and PSU for the entire population, by socioeconomic level measured by parents' level of education: FIGURE A2 PSU compared with SIMCE, by parental education level

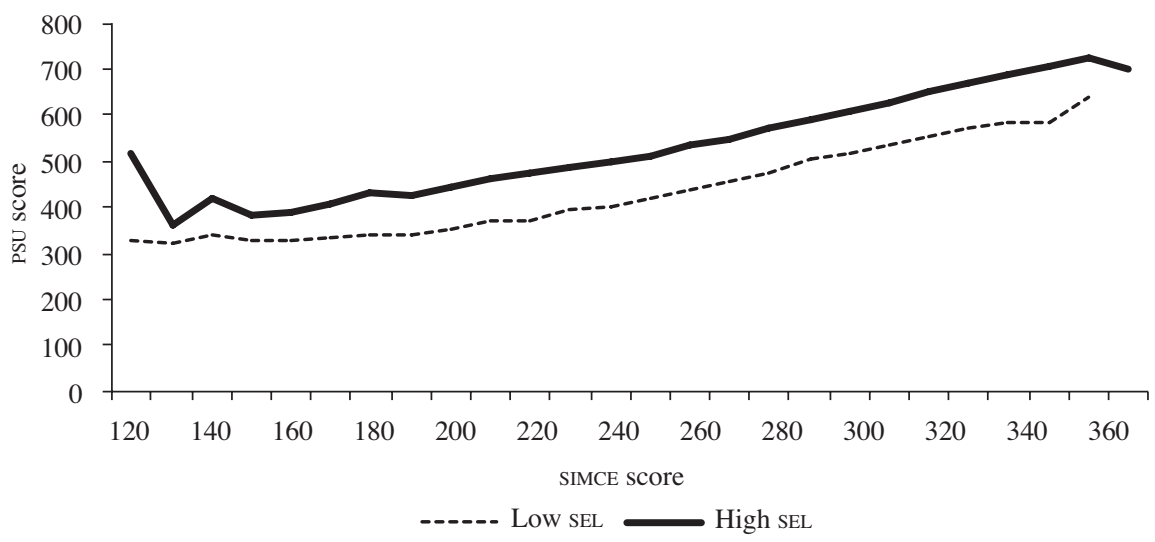

Source: prepared by the authors, on the basis of data from the Educational Quality Measurement System (SIMCE) 2000 and the University Selection Test (PSU) 2004.

SEL: socioeconomic level. 


\section{- Equation (3) including controls for equation (1).}

TABLE A4

PSU by SEL, interaction with SIMCE and controls

\begin{tabular}{|c|c|c|c|}
\hline Variables & PSU Math & PSU Lang & PSU \\
\hline HighseL & $-39.52 * * *$ & $-71.29 * * *$ & $26.28 * * *$ \\
\hline LoWSEL & $-47.78 * * *$ & $-106.1 * * *$ & 4.022 \\
\hline HighSEL SIMCE & $0.204 * * *$ & $0.302 * * *$ & -0.0247 \\
\hline LOWSEL SIMCE & $0.138 * * *$ & $0.356^{* * *}$ & $-0.0440^{* * *}$ \\
\hline SIMCE & & & $1.371 * * *$ \\
\hline SIMCE Math & $1.106^{* * *}$ & & \\
\hline SIMCE Lang & & $0.993 * * *$ & \\
\hline Subsidized & $7.501 * * *$ & $10.51 * * *$ & $8.727 * * *$ \\
\hline Private & $35.39 * * *$ & $35.24 * * *$ & $31.39 * * *$ \\
\hline Modality & $42.48 * * *$ & $35.85 * * *$ & $37.83 * * *$ \\
\hline Female $=1$ & $-34.04 * * *$ & $-19.90 * * *$ & $-27.59 * * *$ \\
\hline Parents' education & $5.342 * * *$ & $6.733 * * *$ & $5.367 * * *$ \\
\hline Rural & $-19.12 * * *$ & $-19.75 * * *$ & $-19.02 * * *$ \\
\hline NEM (relative) & $95.16^{* * *}$ & $92.12 * * *$ & $84.70 * * *$ \\
\hline Constant & $97.97 * * *$ & $118.2^{* * *}$ & $28.41 * * *$ \\
\hline No. observations & 87417 & 87417 & 87417 \\
\hline R-squared & 0.647 & 0.606 & 0.713 \\
\hline
\end{tabular}

Source: prepared by the authors, on the basis of data from the Educational Quality Measurement System (SIMCE) 2000 and the University Selection Test (PSU) 2004.

Note: $* * * \mathrm{p}<0.01$

SEL: socioeconomic level.

NEM: average secondary school grade.

SIMCE Lang: SIMCE language.

SIMCE Math: SIMCE mathematics.

\section{- Two-stage least squares model (MC2E) to resolve selection bias.}

The results obtained using a cohort of students who took the SIMCE test in 2006 and the PSU in 2008 were consistent with those reported in this work. Table A5 shows the results of estimating (3) with the new database.

TABLE A5

PSU by income and interaction with SIMCE

\begin{tabular}{|c|c|c|c|}
\hline Variables & PSU Lang & PSU Math & PSU \\
\hline SIMCE & & & $1.578 * * *$ \\
\hline Low SEL & $-61.01 * * *$ & $22.76^{* * * *}$ & $33.16 * * *$ \\
\hline High SEL & $14.29 * * *$ & $24.00 * * *$ & $69.23 * * *$ \\
\hline LOWSEL SIMCE & $0.0971^{* * *} *$ & $-0.217 * * *$ & $-0.252 * * *$ \\
\hline HighsEL SIMCE & $0.167 * * *$ & $0.126^{* * *}$ & $-0.0409 * * *$ \\
\hline SIMCE Lang & $1.512 * * *$ & & \\
\hline SIMCE Math & & $1.286 * * *$ & \\
\hline Constant & $84.01 * * *$ & $143.0 * * *$ & $64.87 * * *$ \\
\hline No. observations & 145413 & 144762 & 144624 \\
\hline R-squared & 0.632 & 0.656 & 0.738 \\
\hline
\end{tabular}

Source: prepared by the authors, on the basis of data from the Educational Quality Measurement System (SIMCE) 2000 and the University Selection Test (PSU) 2004.

Note: $* * * \mathrm{p}<0.01$.

SIMCE Lang: SIMCE language // SIMCE Math: SIMCE mathematics.

SEL: socioeconomic level. 
The meaning and significance of the main findings are maintained using this new database. With this cohort, it is also possible to resolve the selection bias problem on the basis of a full-information maximum likelihood estimation, similarly to the MC2E methodology proposed by Heckman (1979).

For the purposes of estimation, parents' expectations regarding their children's future studies at the time of the SIMCE were taken as an identification variable. The results are reported in table A6.

TABLE A6

PSU by socioeconomic level and interaction with SIMCE, with Heckman correction for selection bias

\begin{tabular}{|c|c|c|c|c|c|c|}
\hline Variables & PSU Lang & Selection & PSU Math & Selection & PSU & Selection \\
\hline Expectations & & $0.131 * * *$ & & $0.123 * * *$ & & $0.118 * * *$ \\
\hline SIMCE & & & & & $1.524 * * *$ & $0.00990 * * *$ \\
\hline Low SEL & $-38.55 * * *$ & $-0.592 * * *$ & $30.22 * * *$ & $-0.353 * * *$ & $38.91 * * *$ & $0.0739 *$ \\
\hline High SEL & $-15.19 * * *$ & $0.380 * * *$ & $9.247 * *$ & $0.372 * * *$ & $50.88 * * *$ & $0.898 * * *$ \\
\hline LOWSEL SIMCE & $0.0372 * * *$ & $0.00120 * * *$ & $-0.236 * * *$ & 0.000214 & $-0.264 * * *$ & $-0.00153 * * *$ \\
\hline HighsEL SIMCE & $0.241 * * *$ & $0.000878 * *$ & $0.168 * * *$ & 0.000434 & 0.0126 & $-0.00150 * * *$ \\
\hline SIMCE Lang & $1.380 * * *$ & $0.00795 * * *$ & & & & \\
\hline SIMCE Math & & & $1.252 * * *$ & $0.00735 * * *$ & & \\
\hline Constant & $134.6 * * *$ & $-2.163 * * *$ & $157.0 * * *$ & $-1.960 * * *$ & $84.75 * * *$ & $-2.590 * * *$ \\
\hline No. observations & 225265 & 225265 & 225265 & 225265 & 225265 & 225265 \\
\hline
\end{tabular}

Source: prepared by the authors, on the basis of data from the Educational Quality Measurement System (SIMCE) 2000 and the University Selection Test (PSU) 2004.

Note: $* *$ p $<0.01, * * \mathrm{p}<0.05, * \mathrm{p}<0.1$.

SIMCE Lang: SIMCE language // SIMCE Math: SIMCE mathematics.

SEL: Socioeconomic level.

\section{Bibliography}

Arrow, K., S. Bowles and S. Durlauf (eds.) (2000), Meritocracy and Economic Inequality, Princeton, Princeton University Press.

Bourdieu, P. and J.C. Passeron (1964), Los herederos. Los estudiantes y la cultura, Buenos Aires, Siglo Veintiuno Editores.

Brunner, J.J. and G. Elacqua (2003), "Factores que inciden en una educación efectiva. Evidencia internacional", La educación: Revista Interamericana de Desarrollo Educativo, No. 139-140 (I-II), Washington, D.C., Organization of American States (OAS).

Chumacero, R., D. Gómez Caorsi and R. Paredes (2008), "I Would Walk 500 Miles (If it Paid)" [online] http://mpra.ub.unimuenchen.de/15125/.

CRUCH (Consejo de Rectores de las Universidades Chilenas) (2012) [online] http://www.consejoderectores.cl/web/.

Contreras, D. (1999), "Distribución del ingreso en Chile. Nueve hechos y algunos mitos", Perspectivas, vol. 2, No. 2, Santiago, Chile, University of Chile.

(1996), Pobreza y desigualdad en Chile: 1987-1992. Discurso, metodología y evidencia empírica, Santiago, Chile, Centre for Public Studies.

Contreras, D. and S. Gallegos (2011), "Wage inequality in Latin America: a decade of changes", CEPAL Review, No. 103 (LC/G.2487-P), Santiago, Chile.

Contreras, D., S. Gallegos and F. Meneses (2009), Determinantes de desempeño universitario. ¿Importa la habilidad relativa?, Santiago, Chile, National Council for Education.
Contreras, D. and V. Macías (2002), "Desigualdad educacional en Chile: Geografía y dependencia”, Cuadernos de Economía, vol. 39, No. 118, Santiago, Chile, Institute of Economics, Catholic University of Chile.

Contreras, D., P. Sepúlveda and S. Bustos (2007), "When schools are the ones that choose: the effects of screening in Chile", Working Paper, No. 242, Santiago, Chile, University of Chile.

Contreras, M.A., F. Corbalán and J. Redondo (2007), "Cuando la suerte está echada: Estudio cuantitativo de los factores asociados al rendimiento en la PSU", Revista Iberoamericana sobre Calidad, Eficacia y Cambio en Educación, vol. 5, No. 5e, Red Iberoamericana sobre Cambio y Eficacia Escolar (RINACE).

Cornejo, R. and M.J. Redondo (2005), "Variables y factores asociados al aprendizaje escolar. Una discusión desde la investigación actual", Estudios Pedagógicos, vol. 33, No. 2, Valdivia, Facultad de Filosofía y Humanidades, Universidad Austral de Chile.

DEMRE (Departamento de Evaluación, Medición y Registro Educacional) (2012), "La Prueba de Selección Universitaria", Santiago, Chile [online] www.demre.cl/psu.htm>.

ECLAC (Economic Commission for Latin America and the Caribbean) (2010), Time for equality: closing gaps, opening trails (LC/ G.2432(SES.33/3)), Santiago, Chile.

Elacqua, G. and R. Fábrega (2004), El consumidor de la educación: El actor olvidado de la libre elección de escuelas en Chile, Santiago, Chile. 
Elacqua, G., S. González and F. Salazar (n/d), "Educación superior: Acceso, permanencia y perfil social de los graduados comparados con los egresados de la educación media. Apuntes sobre el caso chileno", Information System on Educational Trends in Latin America (SITEAL).

Epple, D. and R. Romano (1998), "Competition between private and public schools, vouchers and peer group effects", American Economic Review, vol. 88, No. 1, Nashville, Tennessee, American Economic Association.

Gallego, F. and A. Hernando (2009), "School choice in Chile: looking at the demand side", Working Paper, No. 356, Santiago, Chile, Institute of Economics, Catholic University of Chile.

González, P. (n/d), "Dos desafíos de equidad desde la economía a la educación", Santiago, Chile, Centre for Applied Economics, University of Chile/United Nations Children's Fund (UNICEF).

Hanushek, E. (1996), "Measuring investment in education", Journal of Economic Perspectives, vol. 10, No. 4, Nashville, Tennessee, American Economic Association.

Hanushek, E. and L. Wößmann (2008), "Education and economic growth", chapter prepared for the International Encyclopedia of Education.

Hanushek, E., S. Rivkin and L. Taylor (1996), "Aggregation and the estimated effects of school resources", The Review of Economics and Statistics, vol. 78, No. 4, Cambridge, Massachusetts, The MIT Press.

Heckman, J. (1979), "Sample selection bias as a specification error", Econometrica, vol. 47, No. 1, New York, The Econometric Society.

Hsieh, C. and M. Urquiola (2006), "The effects of generalized school choice on achievement and stratification: evidence from Chile's voucher program”, Journal of Public Economics, vol. 90, No. 8-9, Amsterdam, Elsevier.

Krueger, A. (2000), 'An Economist's View' of Class Size Research, Santa Monica, Milken Institute.

López-Calva, L. and N. Lustig (2010), Declining Latin America Inequality: Market Forces or State Action?, Washington, D.C., Brookings Institution Press/United Nations Development Programme (UNDP).
McEwan, P. and M. Carnoy (1999), "The Effectiveness and Efficiency of Private Schools in Chile's Voucher System”, Washington, D.C., World Bank.

Mizala, A. and P. Romaguera (2000), "Determinación de factores explicativos de los resultados escolares en educación media en Chile", Serie Economía, No. 85, Santiago, Chile, Centre for Applied Economics, Department of Industrial Engineering, Faculty of Physical and Mathematical Sciences, University of Chile.

Núñez, J. and C. Risco (2004), "Movilidad intergeneracional del ingreso en un país en desarrollo: El caso de Chile", Working Paper, No. 210, Santiago, Chile, Department of Economics, University of Chile.

OECD (Organisation for Economic Cooperation and Development) (2012), "Better Life Index" [online] http://www.oecdbetterlifeindex. org/topics/income/.

(2011), Maintaining Momentum: OECD Perspectives on Policy Challenges in Chile, Paris.

(2007), Education at a Glace 2007: OECD Indicators, Paris.

Puhani, A. (2000), "The Heckman correction for sample selection and its critique", Journal of Economic Surveys, vol. 14, No. 1, Wiley Blackwell.

Redondo, J.M., C. Descouvières y K. Rojas (2004), Equidad y calidad de la educación en Chile: Reflexiones e investigaciones de eficiencia de la educación obligatoria (1990-2001), Santiago, Chile, Department of Social Sciences, University of Chile.

Todd, E. and I. Wolpin (2003), "On the specification and estimation of the production function for cognitive achievement", The Economic Journal, vol. 113, No. 485, Royal Economic Society.

Valenzuela, J. (2006), Evolución de la segregación socioeconómica de los estudiantes chilenos y su relación con el financiamiento compartido, Santiago, Chile, Ministry of Education.

Williamson, J. (2003), An Agenda for Restarting Growth and Reform, Washington, D.C., Institute for International Economics. 